Intecoms: Journal of Information Technology and Computer Science

Volume 1 Nomor 2, Desember 2018

e-ISSN : 2614-1574

p-ISSN : 2621-3249

DOI : https://doi.org/10.31539/intecoms.v1i2.365

\title{
DETEKSI PLAT NOMOR KEDARAAN RODA DUA MENGGUNAKAN METODE EDGE DETECTION
}

\section{DETECTION OF TWO WHEEL VEHICLE NUMBER PLATES USING EDGE DETECTION METHOD}

\author{
Erwin Dwika Putra ${ }^{1}$, Dedy Abdullah ${ }^{2}$ \\ Universitas Muhammadiyah Bengkulu \\ erwindwikap@gmail.com ${ }^{1}$
}

\begin{abstract}
On research done previously for segmentation of vehicle license plates have been on test cobakan method using edge detection to get the edges of characters not quite optimal. Then from the problem on this research will be focused on the detection plates two-wheeled vehicle uses a method of edge detection, where the results of this research will be resized using the technique of measurement of the confusion matrix. where in these measurements will be compared from the entire technique of edge detection, on the results of detection of vehicle license plates. edge detection method on the dispatcher of the good according to the results of the sobel operator i.e. matrix confussion and prewitt operators. With the level of accuracy of $60 \%$ while the sobel operator prewitt $63 \%$ success rate. But on each operator as explained above that still has weaknesses, namely apabil objects more than 2 objects, and when there is excess light reflection around the object that you want to detect.
\end{abstract}

Keywords: Edge Detection, Confussion, Matrix Methods, Detection

ABSTRAK

Pada penelitian yang dilakukan sebelumnya untuk segmentasi plat nomor kendaraan telah di uji cobakan menggunakan metode edge detection untuk mendapatkan tepi karakter belum cukup optimal. Maka dari masalah yang ada pada penelitian ini akan difokuskan pada deteksi pla $t$ nomor kendaraan roda dua menggunakan metode edge detection, dimana hasil dari penelitian ini akan di ukur menggunakan teknik pengukuran confusion matrix. dimana pada pengukuran ini nantinya akan membandingkan dari seluruh teknik edge detection, pada hasil deteksi plat nomor kendaraan. operator pada metode edge detection yang baik menurut hasil confussion matrix yaitu operator sobel dan operator prewitt. Dengan tingkat akurasi sobel $60 \%$ sedangkan operator prewitt $63 \%$ tingkat keberhasilan. Tetapi pada masing-masing operator seperti yang telah dijelaskan diatas bahwa masih mempunyai kelemahan yaitu apabil objek lebih dari 2 objek, dan apabila terdapat pantulan cahaya yang berlebih disekitar objek yang akan di deteksi.

Kata Kunci: Edge Detection, Confussion Matrix, Metode, Deteksi

\section{PENDAHULUAN}

Permasalahan yang sering terjadi pada deteksi plat nomor kendaraan, menurut penelitian yang telah dilakukan sebelumnya (Abdullah et all, 2013), yaitu: Gangguan baut pada plat, gangguan bingkai dan gangguan pantulan bayangan

Dari gangguan atau noise citra pada saat segmentasi plat nomor kendaraan maka muncul masalah bagaimana hasil yang didapatkan pada saat deteksi plat nomor kendaraan (Choudhury, 2016).

Faktor tersebut diatas dapat mempengaruhi setiap penelitian identifikasi plat nomor kendaraan, akan tetapi pada plat nomor kendaraan roda dua terdapat faktor yang tidak kalah penting yaitu jarak antara kendaraan cenderung berdekatan (Serajeh, 2016).

Mengacu pada faktor kesulitan diatas maka pada penelitian ini akan berfokus pada deteksi plat nomor kendaran roda dua, dimana data akan 
diambil dari lahan parkiran. Penyelesaian masalah ini akan dicoba menggunakan salah satu teknik pengolahan citra digital yaitu metode deteksi tepi (edge detection).

Pada penelitian yang dilakukan sebelumnya untuk segmentasi plat nomor kendaraan telah di uji cobakan menggunakan metode edge detection untuk mendapatkan tepi karakter belum cukup optimal (putra et al, 2015).

Maka dari masalah yang ada pada penelitian ini akan difokuskan pada deteksi plat nomor kendaraan roda dua menggunakan metode edge detection, dimana hasil dari penelitian ini akan di ukur menggunakan teknik pengukuran confusion matrix dimana pada pengukuran ini nantinya akan membandingkan dari seluruh teknik edge detection, pada hasil deteksi plat nomor kendaraan (Jia et al, 2007).

\section{METODE PENELITIAN}

Metode penelitian yang digunakan pada penelitian yaitu metode experiment dimana tahapan experiment yaitu: pengumpulan data, pengolahan data, code, eksperimen dan pengujian dan evaluasi (Putra et al, 2015).

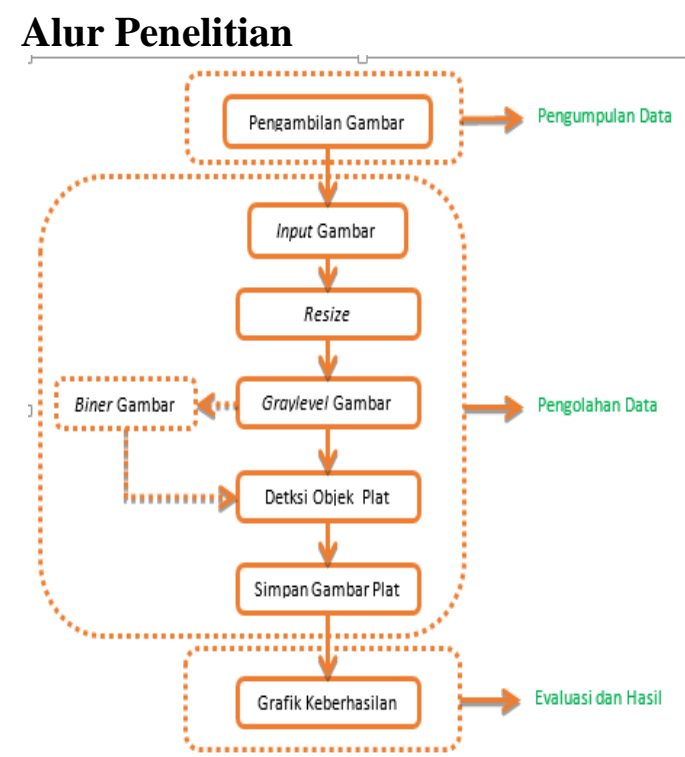

Gambar. 1 Alur Penelitian

\section{Data Testing}

Pada tahapan ini akan dilakukan pengumpulan data dengan menggunakan kamera digital untuk mendapatkan gambar pada plat nomor kendaraan. Pengumpulan data ini akan diambil pada lapangan parkir kampus Universitas Muhammadiyah Bengkulu, dimana lokasi kampus Universitas Muhammadiyah Bengkulu mempunyai 4 lokasi.

Untuk dapat memaksimalkan pengambilan data jarak pengambilan gambar akan diambil lebih kurang 1 meter dari objek yang akan diambil, dikarenakan setiap objek kendaraan bermotor roda nantinya pasti akan berdekatan satu sama lain. Jadi hasil dari gambar yang akan didapatkan bisa lebih dari 1 objek kendaraan bermotor roda dua.
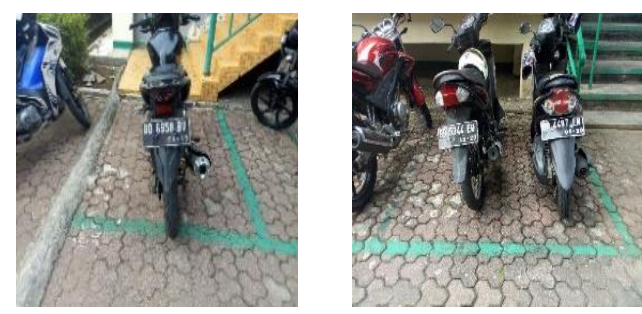

Gambar. 2 Data Image Testing

\section{Data Pustaka}

Secara matematis, perbedaan itentitas pada jarak spasial tertentu dikenal sebagai turunan pertama dari suatu fungsi. Berawal dari konsep tersebut dapat dikembangkan suatu fungsi pendeteksi tepi sederhana yang juga dikenal sebagai gradien citra. Persamaan gradien citra dapat dilihat dibawah ini (Madenda, 2015):

$$
\begin{aligned}
& \nabla I(x, y)= \\
& \sqrt{\left(\nabla I(x, y)_{x}\right)^{2}+\left(\nabla I(x, y)_{y}\right)^{2}}
\end{aligned}
$$

Pada salah satu operasi dasar dari pengolahan citra digital deteksi tepi sangat diperlukan sebelum 
dilakukannya proses segmentasi objek pada citra. Deteksi tepi merupakan batas dari sebuah objek pada citra dimana batas tersebut dapat dideteksi dari perbedaan tingkat keabuannya (Purnomo dan Muntasa, 2010).

Beberapa metode deteksi objek yang banyak digunakan pada pendektesian tepi citra digital, yaitu operator robert, operator prewitt dan operator sobel. Operator Sobel seringkali digunakan untuk mendapatkan tepi sebuah objek karena kesederhanaan dan ketepatannya (putra, 2017). Kelebihan yang sangat bagus pada operator ini adalah menguragi noise sebelum perhitungan untuk mendapatkan tepi objek pada citra (Purnomo dan Muntasa, 2010).

Operator sobel memiliki matriks maskuntuk memberikan respon seacara maksimal terhadap tepi objek secara horizontal maupun vertikal. Masking ini akan diaplikasikan secara terpisah dari input citra. Pada operator sobel memiliki kernel gradient 3 x 3 , mempunyai koefisien yang telah ditentukan. Dapat dinyatakan pada kernel dibawah ini (choundury, 2015):

$$
G_{x}=\left[\begin{array}{lll}
-1 & 0 & 1 \\
-2 & 0 & 2 \\
-1 & 0 & 1
\end{array}\right] \text { dan } G_{y}=\left[\begin{array}{ccc}
1 & 2 & 1 \\
0 & 0 & 0 \\
-1 & -2 & -1
\end{array}\right]
$$

Selanjutnya kernel tersebut akan dilakukan perhitungan nilai antara nilai kernel dengan nilai gambar pada citra, dimana dalam hal ini citra yang akan dihitung adalah kekuatan dari tepi citra dari kekuatan cahayanya. Persamaan tersebut dapat dinyatakan dibawah ini (choundury, 2015):

$$
G=\sqrt{\left(G_{x}^{S}: I\right)^{2}+\left(G_{y}^{S} \div I\right)^{2}}
$$

atau dengan persamaan:

$$
G=\left|G_{x}^{S} * I\right|\left|G_{y}^{S} * I\right|
$$

Operator Roberts menggunakan turunan pertama dari fungsi citra namun arah pendetksian tepinya tidak menggunakan arah horizontal ataupun vertikal tetapi menggunakan arah diagonal $45^{\circ}$ dan $135^{\circ}$. Daimana matriks kernel yang digunakan pada operator ini menggunakan matriks 2 x 2, dijelaskan pada persamaan berikut (abdullah et al, 2017):

$G_{45^{\circ}}=\left(\begin{array}{cc}-1 & 0 \\ 0 & 1\end{array}\right)$ dan $G_{135^{\circ}}=\left(\begin{array}{cc}0-1 \\ 1 & 0\end{array}\right)$

Selanjutnya matriks kernel diatas akan dihitung dengan menggunakan persamaan dibawah ini:

$G=\sqrt{\left(G_{45^{0}} * I\right)^{2}+\left(G_{135^{\circ}} * I\right)^{2}}$

atau dengan persamaan:

$G=\left|G_{45^{\circ}} * I\right|\left|G_{135^{\circ}} * I\right|$

Operator Prewitt menggunakan turunan pertama arah $\mathrm{x}$ akan diikuti oleh sebuah filter arah y. Turunan pertama yang akan digunakan pada operator prewitt adalah turunan antara dua titik $(\mathrm{x}+1, \mathrm{y})$ dan $(\mathrm{x}-1, \mathrm{y})$ serta $(\mathrm{x}, \mathrm{y}+1)$ dan $(\mathrm{x}, \mathrm{y}-1)$. Apabila diuraikan pada sebuah matriks maka akan mendapatkan kernel matriks $3 \times 3$ seperti dibawah ini:

$G_{x}^{p}=\left[\begin{array}{lll}-1 & 0 & 1 \\ -1 & 0 & 1 \\ -1 & 0 & 1\end{array}\right]$ dan $G_{y}^{p}=\left[\begin{array}{ccc}-1 & -1 & -1 \\ 0 & 0 & 0 \\ 1 & 1 & 1\end{array}\right]$

Selanjutnya matriks kernel diata akan dihitung dengan menggunakan persamaan dibawah ini:

$G=\sqrt{\left(G_{x}^{p} * I\right)^{2}+\left(G_{y}^{p} * I\right)^{2}}$

atau dengan persamaan:

$$
G=\left|G_{x}^{P}: I\right|\left|G_{y}^{P} \div I\right|
$$


HASIL DAN PEMBAHASAN

Hasil penelitian ini berupa data tabel menggunakan hasil perhitungan confussion matrix, dengan hasil dapat dilihat pada tabel berikut:

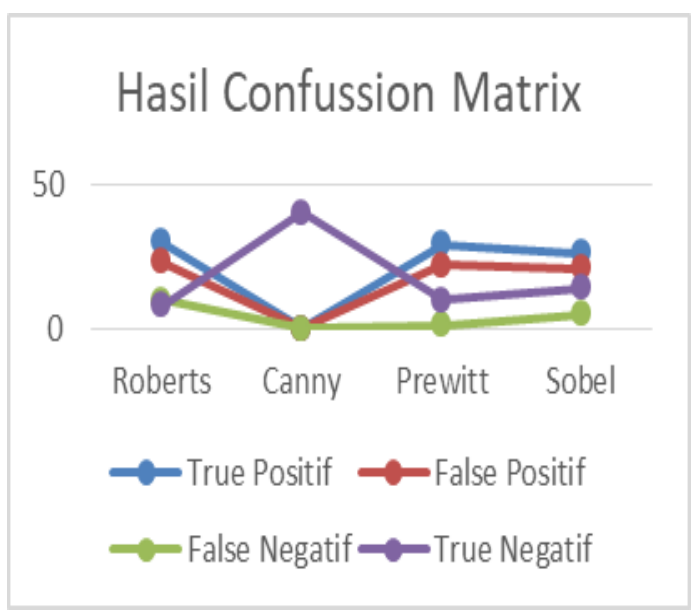

Gambar. 3 Grafik Confussion Matrix

Melihat dari hasil grafik diatas maka pada teknik edge detection, yang paling banyak mendapatkan nilai True Positif (TP) adalah Roberts dan Prewitt, karena pada nilai TP merupakan nilai banyaknya image yang dapat mendeteksi plat nomor kendaraan roda dua dengan benar.

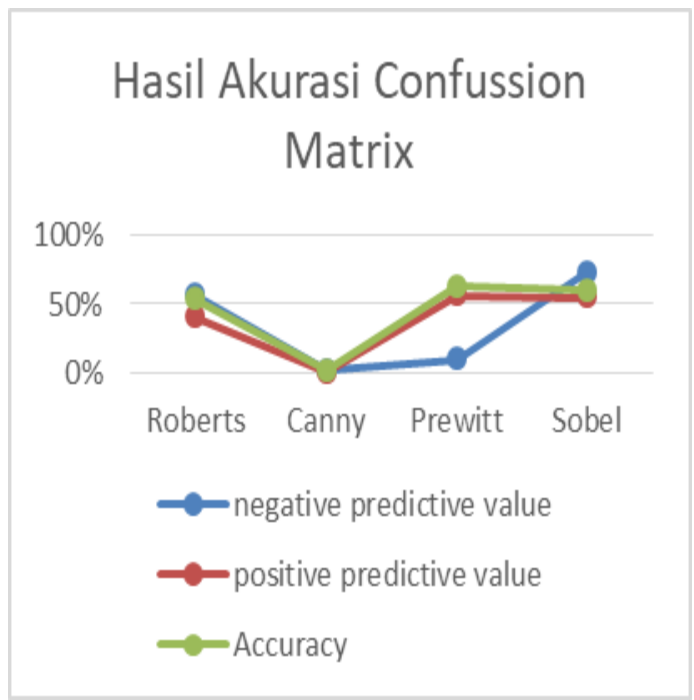

Gambar. 4 Grafik Akurasi Confussion Matrix
Pada masing-masing teknik terdapat kelemahan yaitu tidak dapatnya mendeteksi objek lebih dari satu objek, sedangkan untuk canny tidak dapat mendeteksi objek dikarenakan tepi yang didapatkan terlalu spesifik untuk setiap tepi pada image yang diuji cobakan.

\section{SIMPULAN}

Pada penelitian ini dapat disimpulkan bahwa operator pada metode edge detection yang baik menurut hasil confussion matrix yaitu operator sobel dan operator prewitt. Dengan tingkat akurasi sobel $60 \%$ sedangkan operator prewitt $63 \%$ tingkat keberhasilan.

Tetapi pada masing-masing operator seperti yang telah dijelaskan diatas bahwa masih mempunyai kelemahan yaitu apabil objek lebih dari 2 objek, dan apabila terdapat pantulan cahaya yang berlebih disekitar objek yang akan di deteksi.

\section{DAFTAR PUSTAKA}

Abdullah, D., \& Putra, E. D. (2013). Komparasi Metode Otsu dengan Metode Fuzzy Cmeans pada Hasil Segmentasi Identifikasi Karakter Plat Nomor Kendaraan Indonesia. Telematik, 6(4), 1475-84

Choudhury, A., \& Negi, A. (2016). A New Zone Based Algorithm for Detection of License Plate From Indian Vehicle. International Connference on Parallel. ISSN : 370 - 374. ISBN. 978-1-50903669-1

Serajeh, A. (2016). Two Lines Iranian License Plate Detection and Recognition using Subspace Learning. Signal Processing and Intelligent Systems (ICSPIS), International Conference of. ISBN: 978-1-5090-5820-4

Jia, X. W., Li, W., \& Wang, H. (2007). A Novel Algorithm for Character 
Segmentation of Degraded License Plate Based on Prior Knowledge. Automation and Logistics. Automation and Logistics IEEE International Conference on: 249-53. http://ieeexplore.ieee.org/xpls/abs _all.jsp?arnumber $=4338565$

Putra, E. D. (2017). Peningkatan Segmentasi pada Identifikasi Plat Nomor Kendaraan Indonesia Menggunakan Metode Otsu dengan Gaussian. $J$. Pseudocode, 4(44)

Putra, E. D., \& Santosa, S. (2017). Optimasi Kemampuan Segmentasi Otsu pada Identifikasi Plat Nomor Kendaraan Indonesia Menggunakan Metode Gaussian. Jurnal Pseudocode, 4(1), 47-60

Abdullah, D., \& Putra, E. D. (2017). Komparasi Perbaikan Kualitas Segmentasi pada Citra Digital Metode Fuzzy C-means dan Otsu. Jurnal Pseudocode, 4(1), 71-80

Muntasa, A., \& Purnomo, M. H. (2010). Konsep Pengolahan Citra Digital dan Ekstraksi fitur. Yogyakarta: Graha Ilmu

Peraturan Pemerintah.

(1993). Peraturan Pemerintah 